\title{
Indications and epidemiological profile of patients submitted
}

\author{
Indicações e perfil epidemiológico dos pacientes \\ submetidos à ceratoplastia
}

Augusto Adam Nettoํㅡㄹ Caio Augusto Schlindwein Botelho², Lucas Costa Felicíssimo²

\begin{abstract}
Purpose: To define the epidemiological aspects of the patients submitted to keratoplasty in the state of Santa Catarina, Brazil and the main indications for this procedure. Methods: We conducted an observational, descriptive and retrospective study with the data of 1161 patients submitted to cornea transplantation from january 2008 to december 2010, at the Transplantation Center of Santa Catarina. The analyzed data were: age, gender, origin, transplant date, indication and transplanted eye. Results: The mean age was 45.51 years and men were more commonly operated. Keratoconus was the most common disease (36.09\%), followed by graft failure (15.89\%), leukoma (11.92\%), bullous keratopathy (11.06\%), dystrophy (7.77\%), ulcer (5.36\%), corneal perforation $(5.27 \%)$, descemetocel $(4.66 \%)$, herpetic keratitis $(1.12 \%)$ and corneal ectasia $(0.86 \%)$. The region with the greater number of cases was the Great Florianopolis $(23.75 \%)$, with keratoconus as the main indication $(30.91 \%)$. Leukoma and perforation were the mainly indication in patients under 10 years old, keratoconus in patients between 11 and 50 years old, graft failure between 51 and 60 years old and bullous keratopathy in patients under 61 years old. Conclusion:Keratoconus is the main indication for keratoplasty in our state, with the mean age of 31 years. Most of the patients were men and from the Great Florianopolis.
\end{abstract}

Keywords: Cornea, Corneal transplantation; Keratoplasty, penetrating; Corneal disease; Keratoconus; Health profile

\begin{abstract}
Resumo
Objetivo: Avaliar o perfil epidemiológico dos pacientes submetidos à ceratoplastia no estado de Santa Catarina e as principais indicações para este procedimento. Métodos: Foi realizado estudo observacional, descritivo e retrospectivo com dados de 1161 pacientes transplantados entre janeiro de 2008 e dezembro de 2010, de acordo com os prontuários obtidos na Central de Notificação, Captação e Distribuição de Órgãos e Tecidos de Santa Catarina. As variáveis registradas foram: idade, sexo, procedência, data do transplante, indicação e olho operado. Resultados: A média de idade foi de 45,51 anos e o sexo masculino foi mais prevalente $(54,05 \%)$. O ceratocone foi a doença mais frequente $(36,09 \%)$, seguido por falência do enxerto $(15,89 \%)$, leucoma $(11,92 \%)$, ceratopatia bolhosa $(11,06 \%)$, distrofias $(7,77 \%)$, úlcera $(5,36 \%)$, perfuração corneana $(5,27 \%)$, descemetocele $(4,66 \%)$, ceratite herpética $(1,12 \%)$ e ectasia corneana $(0,86 \%)$. A região do estado com maior número de casos foi a Grande Florianópolis $(23,75 \%)$, sendo o ceratocone a principal indicação $(30,91 \%)$. Leucoma e perfuração foram as principais indicações em pacientes com idade inferior a 10 anos, ceratocone nos pacientes entre 11 e 50 anos, falência do enxerto entre 51 e 60 anos e ceratopatia bolhosa nos pacientes acima de 61 anos. Conclusão: O ceratocone é a principal indicação para ceratoplastia no estado de Santa Catarina, com a média de idade de 31 anos. A maioria dos pacientes é do sexo masculino e proveniente da Grande Florianópolis.
\end{abstract}

Descritores: Córnea; Transplante de córnea; Ceratoplastia penetrante; Doenças da córnea; Ceratocone; Perfis de saúde

1. Professor of Ophthalmology, Department of Surgery, Federal University of Santa Catarina (UFSC), Florianópolis/SC, Brazil.

2. Medical Student, Federal University of Santa Catarina (UFSC), Florianópolis/SC, Brazil.

Institution: Federal University of Santa Catarina (UFSC)Polydoro Ernani University Hospital Department of Surgery

The authors declare no conflict of interest.

Received for publication 5/10/2012 - Accepted for publication 20/10/2013 


\section{INTRODUCTION}

$\mathbf{F}$ or years, physicians attempted to restore damaged corneas without success. It was only in the mid-19th century that Powers (1878) and other surgeons conducted studies that elucidated the physiology of corneal tissue, which provided Eduard Zirm the knowledge and techniques necessary to perform the first successful penetrating keratoplasty in $1905^{(1-4)}$. Corneal transplantation can be classified according to: biological type (autograft, where the donated cornea and the host eye are from the same individual; allograft, where the cornea is transplanted between individuals of the same species; and xenograft, where the donated cornea and the host eye are from individuals of different species); surgical technique (lamellar, where only a part of the corneal thickness is replaced; and penetrating, where the entire tissue is replaced); and transplanted portion (partial, where part of the diameter is transplanted; and total, where the entire diameter is transplanted) $)^{(5,6)}$.

The cornea is currently the most frequently transplanted tissue in the United States, Europe ${ }^{(7)}$, and, since 1998, Brazil $^{(8,9)}$. Transplantation is done for optical, reconstructive, therapeutic, or cosmetic reasons ${ }^{(5,6)}$. The increasing number of transplants is explained by improved organisation of eye banks, better selection of donated tissue, and advances in pharmacology, immunology, and eye microsurgery, allowing transplants in situations previously considered inoperable ${ }^{(6,10)}$. In Brazil, the National Transplant System (Sistema Nacional de Transplantes [SNT]), working through each state's Organ Notification, Collection and Distribution Unit (CNCDO), coordinates the Human Eye Tissue Banks, which are responsible for the logistics and storage of collected corneas and the registration of donors and recipients ${ }^{(11)}$.

Several studies have been conducted in Brazil ${ }^{(2,3,5,6,6,9,12-15)}$ and worldwide ${ }^{(4,7,16-24)}$ to determine the epidemiological characteristics of patients and the main indications for corneal transplantation in different regions and services. This study aimed to outline the social and clinical profile of patients undergoing keratoplasty in the state of Santa Catarina, Brazil, and to assess the leading indications for transplantation.

\section{Methods}

This was an observational and descriptive study on patients undergoing keratoplasty between January 2008 and December 2010. Data were collected retrospectively from the records of Santa Catarina's CNCDO (CNCDO-SC) using SNT version 5.0. A total of 1,161 charts were evaluated, and three were excluded because they had incomplete data. The following variables were collected: age, sex, origin, transplant date, indication, and operated eye. The type of keratoplasty was not considered as a variable, since it was not listed in the database.

The patients' cities of origin were grouped into regions according to the classification of the Brazilian Institute of Geography and Statistics (IBGE): Greater Florianópolis, North, West, Mountain Region, South, and Itajaí Valley ${ }^{(25)}$. Patients from cities outside Santa Catarina were included in the Other States group.

Transplant indications were classified into: herpetic keratitis, keratoconus, bullous keratopathy, descemetocele, corneal dystrophies, corneal ectasias, graft failure, leukoma, corneal ulcer, and corneal perforation.

Microsoft Excel ${ }^{\mathrm{TM}} 2010$ was used to organise and analyse the data. Data were expressed as means, standard deviations (SD), and percentages.

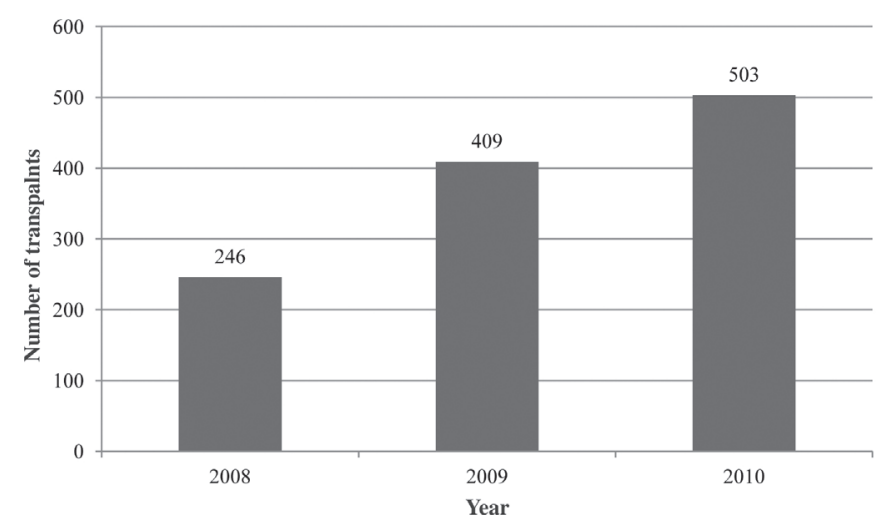

Figure 1: Number of transplants performed between 2008 and 2010; CNCDO-SC.

This study was registered on the Plataforma Brasil register of the Brazilian Ministry of Health under Protocol CAAE 01062812.3.0000.0121.

\section{Results}

Of the 1,158 patients subjected to transplantation during the study period, 652 were male $(56.30 \%)$ and 506 were female $(43.70 \%)$. Patient age ranged from 0 to 93 years; mean age was 45.51 (SD 19.75). In total, $626(54.05 \%)$ transplants were performed in the right eye and $532(45.95 \%)$ in the left eye.

The time distribution was as follows: 246 keratoplasties $(21.24 \%)$ in $2008,409(35.32 \%)$ in 2009 , and $503(43.44 \%)$ in 2010 (Figure 1).

Regarding indications, keratoconus accounted for 418 cases $(36.09 \%)$, and patients had a mean age of 31 years (SD 10.73); graft failure, 184 cases $(15.89 \%)$, mean age 52 years (SD 17.62); leukoma, 138 cases (11.92\%), mean age 47 years (SD 18.50); bullous keratopathy, 128 cases $(11.06 \%)$, mean age 68 years (SD 13.74); dystrophies, 90 cases $(7.77 \%)$, mean age 57 years (SD $20.41)$; ulcer, 62 cases $(5.36 \%)$, mean age 54 years (SD 20.41); corneal perforation, 61 cases $(5.27 \%)$, mean age 50 years (SD $21.08)$; descemetocele, 54 cases $(4.66 \%)$, mean age 46 years (SD 21.38); herpetic keratitis, 13 cases $(1.12 \%)$, mean age 40 years (SD 18.05); and corneal ectasias, 10 cases $(0.86 \%)$, mean age 41 years (SD 7.77; Table 1).

Table 1

Indications for corneal transplantation between 2008 and 2010; CNCDO-SC.

\begin{tabular}{lccc}
\hline Indications & $\mathbf{N}$ & $\mathbf{\%}$ & $\begin{array}{c}\text { Mean age } \\
\mathbf{D} \text { DP (years) }\end{array}$ \\
\hline Keratoconus & 418 & 36,09 & $31 \pm 10,73$ \\
Graft failure & 184 & 15,89 & $52 \pm 17,62$ \\
Leukoma & 138 & 11,92 & $47 \pm 18,50$ \\
Bullous keratopathy & 128 & 11,06 & $68 \pm 13,74$ \\
Corneal dystrophies & 90 & 7,77 & $57 \pm 14,69$ \\
Corneal ulcer & 62 & 5,36 & $54 \pm 20,41$ \\
Corneal perforation & 61 & 5,27 & $50 \pm 21,08$ \\
Descemetocele & 54 & 4,66 & $46 \pm 21,38$ \\
Herpetic keratitis & 13 & 1,12 & $40 \pm 18,05$ \\
Corneal ectasia & 10 & 0,86 & $41 \pm 7,77$ \\
Total & 1158 & 100 & $45,5 \pm 19,76$ \\
& & &
\end{tabular}


Table 2

Age distribution of indications for corneal transplantation (2008-2010); CNCDO-SC.

\begin{tabular}{|c|c|c|c|c|c|c|c|c|c|c|}
\hline \multirow[t]{2}{*}{ Causes } & & \multicolumn{9}{|c|}{ Age (years) } \\
\hline & & $\leq \mathbf{1 0}$ & $11-20$ & 21-30 & $31-40$ & $41-50$ & $51-60$ & $61-70$ & $71-80$ & $>80$ \\
\hline \multirow{2}{*}{ Herpetic keratitis } & $\mathrm{n}$ & 0 & 2 & 2 & 3 & 3 & 1 & 1 & 1 & 0 \\
\hline & $\%$ & 0 & 2,47 & 0,77 & 1,77 & 1,81 & 0,60 & 0,73 & 0,77 & 0 \\
\hline \multirow[t]{2}{*}{ Keratoconus } & $\mathrm{n}$ & 0 & 52 & 191 & 97 & 51 & 22 & 5 & 0 & 0 \\
\hline & $\%$ & 0 & 64,20 & 73,46 & 57,40 & 30,72 & 1,25 & 3,68 & 0 & 0 \\
\hline \multirow[t]{2}{*}{ Bullous keratopathy } & $\mathrm{n}$ & 0 & 1 & 2 & 3 & 7 & 17 & 33 & 48 & 17 \\
\hline & $\%$ & 0 & 1,23 & 0,77 & 1,77 & 4,22 & 10,24 & 24,26 & 36,92 & 43,59 \\
\hline \multirow[t]{2}{*}{ Descemetocele } & $\mathrm{n}$ & 2 & 3 & 14 & 4 & 6 & 7 & 10 & 5 & 3 \\
\hline & $\%$ & 18,18 & 3,70 & 5,38 & 2,37 & 3,61 & 4,22 & 7,35 & 3,85 & 7,69 \\
\hline \multirow[t]{2}{*}{ Dystrophies } & $\mathrm{n}$ & 0 & 1 & 3 & 7 & 17 & 19 & 24 & 18 & 1 \\
\hline & $\%$ & 0 & 1,23 & 1,15 & 4,14 & 10,24 & 11,44 & 17,65 & 13,85 & 2,56 \\
\hline \multirow[t]{2}{*}{ Corneal ectasia } & $\mathrm{n}$ & 0 & 0 & 2 & 2 & 5 & 1 & 0 & 0 & 0 \\
\hline & $\%$ & 0 & 0 & 0,77 & 1,18 & 3,01 & 0,60 & 0 & 0 & 0 \\
\hline \multirow[t]{2}{*}{ Graft failure } & $\mathrm{n}$ & 2 & 7 & 16 & 24 & 30 & 46 & 27 & 26 & 6 \\
\hline & $\%$ & 18,18 & 6,64 & 6,15 & 14,2 & 18,01 & 27,71 & 19,85 & 20,00 & 15,38 \\
\hline \multirow[t]{2}{*}{ Leukoma } & $\mathrm{n}$ & 3 & 9 & 18 & 15 & 27 & 34 & 18 & 11 & 3 \\
\hline & $\%$ & 27,27 & 11,11 & 6,92 & 8,87 & 16,26 & 20,48 & 13,23 & 8,46 & 7,69 \\
\hline \multirow{2}{*}{ Corneal perforation } & $\mathrm{n}$ & 3 & 2 & 8 & 6 & 12 & 7 & 10 & 9 & 4 \\
\hline & $\%$ & 27,27 & 2,47 & 3,08 & 3,55 & 7,23 & 4,22 & 7,35 & 6,92 & 10,26 \\
\hline \multirow[t]{2}{*}{ Ulcer } & $\mathrm{n}$ & 1 & 4 & 4 & 8 & 8 & 12 & 8 & 12 & 5 \\
\hline & $\%$ & 9,09 & 4,94 & 1,54 & 4,73 & 4,82 & 7,23 & 5,88 & 9,23 & 12,82 \\
\hline \multirow[t]{2}{*}{ Total } & $\mathrm{n}$ & 11 & 81 & 260 & 169 & 166 & 166 & 136 & 130 & 39 \\
\hline & $\%$ & 100 & 100 & 100 & 100 & 100 & 100 & 100 & 100 & 100 \\
\hline
\end{tabular}

Table 3

Origin of patients undergoing keratoplasty between 2008 and 2009 according to the IBGE classification; CNCDO-SC.

\begin{tabular}{lcc}
\hline \multicolumn{1}{c}{ Origin } & N & \% \\
\hline Greater Florianópolis & 275 & 23,75 \\
West & 258 & 22,28 \\
Itajaí Valley & 227 & 19,60 \\
North & 207 & 18,05 \\
South & 112 & 9,67 \\
Mountain Region & 61 & 5,27 \\
Other States* & 16 & 1,38 \\
\hline Total & 1158 & 100 \\
\hline
\end{tabular}

(*) Minas Gerais, Paraná and Rio Grande do Sul

The most frequent indications for each age group were: 0 10 years, leukoma and corneal perforation with three cases each (27.27\% each); $11-20$ years, keratoconus with 52 cases $(64.20 \%)$; 21-30 years, keratoconus with 191 cases $(73.46 \%)$; 31-40 years, keratoconus with 97 cases $(57.40 \%)$; 41-50 years, keratoconus with 52 cases $(30.72 \%)$; 51-60 years, graft failure with 46 cases (27.71\%); 61-70 years, bullous keratopathy with 33 cases (24.26\%); 71-80 years, bullous keratopathy with 48 cases $(36.92 \%)$; and 81 years or more, bullous keratopathy with 17 cases $(43.59 \%$; Table 2$)$.

The distribution according to region of origin was as follows: Greater Florianópolis, 275 cases (23.75\%); West, 258 ca-

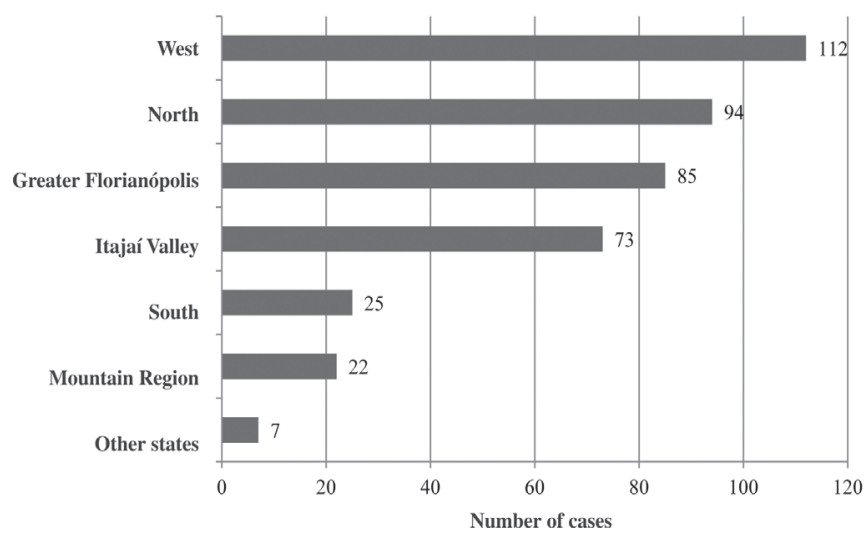

Figure 2: Distribution of keratoconus as main indication for keratoplasty between 2008 and 2010, according to the patient's region of origin; CNCDO-SC

ses (22.28\%); Itajaí Valley, 227 cases (19.60\%); North, 207 cases (18.05\%); South, 112 cases (9.67\%); Mountain Region, 61 cases $(5.27 \%)$; and Other States, 16 cases (1.38\%; Table 3$)$.

In every region of Santa Catarina State keratoconus was the main indication for corneal transplantation: Greater Florianópolis, 85 cases (30.91\%); North, 94 cases (44.98\%); West, 112 cases $(43.41 \%)$; Mountain Region, 22 cases (36.06\%); South, 25 cases $(22.32 \%)$; and Itajaí Valley, 73 cases $(32.16 \%)$. In patients from other states, keratoconus was also the main indication for keratoplasty with seven cases $(43.75 \%$; Figure 2$)$. The complete data on prevalence according to origin is shown in Table 4 . 
Table 4

Distribution of indications for corneal transplantation by region of origin (2008-2010); CNCDO-SC.

\begin{tabular}{|c|c|c|c|c|c|c|c|}
\hline Indication & $\begin{array}{c}\text { Greater } \\
\text { Florianópolis } \\
\text { N(\%) }\end{array}$ & $\begin{array}{l}\text { North } \\
\text { N(\%) }\end{array}$ & $\begin{array}{l}\text { West } \\
\text { N(\%) }\end{array}$ & $\begin{array}{l}\text { Mountain } \\
\text { Region } \\
\text { N(\%) }\end{array}$ & $\begin{array}{l}\text { South } \\
\text { N(\%) }\end{array}$ & $\begin{array}{l}\text { Itajaí } \\
\text { Valley } \\
\mathbf{N}(\%)\end{array}$ & $\begin{array}{l}\text { Other } \\
\text { States } \\
\text { N(\%) }\end{array}$ \\
\hline Herpetic keratitis & $1(0,36)$ & $3(1,43)$ & $6(2,32)$ & $0(0,00)$ & $3(2,68)$ & $0(0,00)$ & $0(0,00)$ \\
\hline Keratoconus & $85(30,9)$ & $94(44,98)$ & $112(43,41)$ & $22(36,06)$ & $25(22,32)$ & $73(35,16)$ & $7(43,74)$ \\
\hline Bullous keratopathy & $25(9,09)$ & $30(14,35)$ & $14(5,43)$ & $5(8,20)$ & $17(15,18)$ & $36(15,86)$ & $1(6,25)$ \\
\hline Descemetocele & $14(5,09)$ & $3(1,43)$ & $11(4,26)$ & $5(8,20)$ & $7(6,25)$ & $12(5,29)$ & $2(12,5)$ \\
\hline Dystrophies & $46(16,73)$ & $20(9,57)$ & $6(2,32)$ & $1(1,64)$ & $2(1,78)$ & $15(6,61)$ & $0(0,00)$ \\
\hline Corneal ectasia & $2(0,73)$ & $3(1,43)$ & $1(0,39)$ & $1(1,64)$ & $1(0,89)$ & $2(0,88)$ & $0(0,00)$ \\
\hline Graft failure & $61(22,18)$ & $19(9,09)$ & $46(17,83)$ & $12(19,67)$ & $19(16,96)$ & $24(10,57)$ & $3(18,75)$ \\
\hline Leukoma & $21(7,64)$ & $20(9,57)$ & $38(14,73)$ & $12(19,67)$ & $14(12,5)$ & $31(13,66)$ & $2(12,5)$ \\
\hline Corneal perforation & $6(2,18)$ & $7(3,35)$ & $11(4,26)$ & $2(3,28)$ & $15(13,39)$ & $20(8,81)$ & $0(0,00)$ \\
\hline Corneal ulcer & $14(5,09)$ & $10(4,78)$ & $13(5,04)$ & $1(1,64)$ & $9(8,03)$ & $14(6,17)$ & $1(6,25)$ \\
\hline Total & $275(100)$ & 209 (100) & $258(100)$ & $61(100)$ & $112(100)$ & 227 (100) & $16(100)$ \\
\hline
\end{tabular}

\section{Discussion}

The present study retrospectively and descriptively evaluated 1,158 records of corneal transplants performed between January 2008 and December 2010. Data were obtained from CNCDO-SC using SNT version 5.0. A nearly linear annual increase in the number of transplants was observed, as previously described by Maeno et al. ${ }^{(17)}$, probably due to the increasing number of donors, better coordination between eye banks and CNCDO-SC, and improvements in surgical technique ${ }^{(16)}$.

Most patients were male $(56.30 \%)$, a finding similar to most other studies ${ }^{(2-5,7,8,12,15,19,21,22)}$. Few studies found a predominance of females ${ }^{(6,16)}$. Mean patient age was 45.51 years, which is also in agreement with the literature ${ }^{(2-6,8,13,23)}$.

Keratoconus was the main indication for corneal transplantation $(36.09 \%)$, similar to a study conducted in the city of Florianópolis where $28.7 \%$ of transplants had this indication $^{(5)}$. Keratoconus is a bilateral corneal ectasia typically affecting older teens and young adults ${ }^{(26)}$, which corresponds to the mean age for the disease found in our study $(31 \pm 10.73$ years) and also in Garcia et al. (27.2 years) ${ }^{(5)}$, Al-Yousuf et al. $(32.5 \pm 11.70 \text { years })^{(7)}$, Maeno et al. (34.43 years) $)^{(17)}$, and Edwards et al. $(31.8 \text { years })^{(21)}$.

Graft failure (and consequent retransplantation) was more frequent in our study ( $22.18 \%$ of cases in Florianópolis) than in Garcia et al. $(8.3 \%)^{(5)}$; this finding partially contradicts the analysis by Kanavi et al. ${ }^{(22)}$, according to whom the number of retransplantations will tend to decrease over time. Dobbins et al. ${ }^{(16)}$ state that improvements in technology and surgical skills lead to an increase in the number of transplants, resulting in more patients with the potential to develop graft failure. Moreover, with the increased incidence of retransplantation this group will continue to grow, since the chances of graft survival decrease after each successive retransplantation ${ }^{(18)}$. This might explain why graft failure was the second leading indication $(15.89 \%)$ in our population.

Leukoma, which was the third leading indication in our sample $(11.92 \%)$, had a variable incidence in previous studies ${ }^{(8,9,12-}$ ${ }^{15,22,23)}$. Because leukoma is a sign rather than a diagnosis, it can be difficult to determine its aetiology and thus its actual incidence, resulting in errors in completing the medical record ${ }^{(15)}$.
Bullous keratopathy, the main indication in some studies $^{(15,16,18,19)}$, was the fourth leading indication in our study $(11.06 \%)$, with a high frequency in patients older than 60 years ( $31.13 \%$ of transplants, mean age $68 \pm 13.74$ years). This is because bullous keratopathy is the main complication of phacoemulsification and intraocular implants, which are increasingly popular procedures since the $1980 \mathrm{~s}^{(3,4)}$. However, considering that in the study by Garcia et al. ${ }^{(5)}$ bullous keratopathy was the third most frequent indication in Florianopólis, it can be assumed that improvements in the surgical technique, as well as intraocular lenses of better quality and greater use of viscoelastic substances to protect the corneal endothelium, have reduced the incidence of this postoperative complication ${ }^{(13,16,24)}$.

It is important to emphasise that the data classification used by SNT is based on the diagnoses made by the professionals involved in transplantation, rather than following a rigorous protocol. This creates difficulties in grouping the diagnoses that led to the indication of keratoplasty.

The distribution of indications by age is shown in Table 2 . For patients younger than 10 years, leukoma and corneal perforation shared first place $(27.27 \%$ each), a finding similar to Pimentel et al. ${ }^{(27)}$. In our study, keratoconus was the leading indication for transplantation in patients aged 11-50 years, in agreement with a study conducted by Flores et al. ${ }^{(3)}$ in 2007 at the University of Campinas. Both studies also agreed regarding patients aged 71-80 years, where bullous keratoplasty was the main indication, mainly because of the high number of phacoemulsification procedures performed in this age group. However, differences were observed among the various studies for other age groups.

The time constraints and the findings of this study are an incentive to conduct further research in order to assess whether the observed trends are maintained.

\section{Conclusion}

The present study retrospectively and descriptively evaluated 1,158 records of corneal transplants performed between January 2008 and December 2010. Data were obtained 
from CNCDO-SC using SNT version 5.0. A nearly linear annual increase in the number of transplants was observed, as previously described by Maeno et al. ${ }^{(17)}$, probably due to the increasing number of donors, better coordination between eye banks and CNCDO-SC, and improvements in surgical technique ${ }^{(16)}$.

\section{ReferenCes}

1. Moffatt SL, Cartwright VA, Stumpf TH. Centennial review of corneal transplantation. Clin Experiment Ophthalmol. 2005;33(6):642-57. Comment in Clin Experiment Ophthalmol. 2006;34(4):387-8.

2. Fabris C, Corrêa ZM, Marcon AS, Castro TN, Marcon IM, Pawlowski C. Estudo retrospectivo dos transplantes penetrantes de córnea da Santa Casa de Porto Alegre. Arq Bras Oftalmol. 2001;64(5):449-53.

3. Flores VG, Dias HL, Castro RS. Indicações para ceratoplastia penetrante no Hospital das Clínicas - UNICAMP. Arq Bras Oftalmol. 2007;70(3):505-8.

4. Xie L, Song Z, Zhao J, Shi W, Wang F. Indications for penetrating keratoplasty in north China. Cornea. 2007;26(9):1070-3.

5. Garcia EL, Adam Netto A, Mendes IR. Indicações para os transplantes de córnea em Florianópolis, Santa Catarina. Rev Bras Oftalmol. 2002;61(3):186-92.

6. Sano FT, Dantas PE, Silvino WR, Sanchez JZ, Sano RY, Adams F, et al. Tendência de mudança nas indicações de transplante penetrante de córnea. Arq Bras Oftalmol. 2008;71(3):400-4.

7. Al-Yousuf N, Mavrikakis I, Mavrikakis E, Daya SM. Penetrating keratoplasty: indications over a 10 year period. Br J Ophthalmol. 2004;88(8):998-1001.

8. Neves RC, Boteon JE, Santiago AP. Indicações de transplante de córnea no Hospital São Geraldo da Universidade Federal de Minas Gerais. Rev Bras Oftalmol. 2010;69(2):84-8.

9. Amaral CS, Duarte JY, Silva PL, Valbuena R, Cunha F. Indicações de ceratoplastia penetrante em Pernambuco. Arq Bras Oftalmol. 2005;68(5):635-7.

10. Silva RF, Vargas NU, Rocha GA, Freitas ML, Souza LB, Moreno $\mathrm{NP}$, et al. Avaliação de tecido corneano processado por um Banco de Olhos de referência. Arq Bras Oftalmol. 2009;72(5):673-6.

11. Brasil. Ministério da Saúde. Portaria n ${ }^{\circ} 2600$, de 21 de outubro de 2009. Aprova o Regulamento Técnico do Sistema Nacional de Transplantes.[atualizado 22 out 2009]; Secção: 1:11. Disponível em: http://www.brasilsus.com.br/legislacoes/gm/101249-2600.html

12. Calix Netto MJ, Giustina ED, Ramos GZ, Peccini RF, Sobrinho M, Souza LB. Principais indicações de transplante penetrante de córnea em um serviço de referência no interior de São Paulo (Sorocaba - SP, Brasil). Arq Bras Oftalmol. 2006;69(5):661-4.

13. Cattani S, Kwitko S, Kroeff MA, Marinho D, Rymer S, Bocaccio FL. Indicações de transplante de córnea no Hospital de Clínicas de Porto Alegre. Arq Bras Oftalmol. 2002;65(1):95-8.
14. Teixeira MF, Almeida Jr GC, Rodrigues ML, Kamimoto PS, Kashiwabuchi LK. Resultados e indicações de ceratoplastias penetrantes realizadas por médicos em treinamento, num país em desenvolvimento. Arq Bras Oftalmol. 2001;64(6):557-61.

15. Araujo AA, Melo GB, Silva RL, Neta VM. Perfil epidemiológico dos pacientes na lista de espera para transplante de córnea no Estado de Sergipe. Arq Bras Oftalmol. 2004;67(4):613-6.

16. Dobbins KR, Price FW Jr, Whitson WE. Trends in the indications for penetrating keratoplasty in the midwestern United States. Cornea. 2000;19(6):813-6.

17. Maeno A, Naor J, Lee HM, Hunter WS, Rootman DS. Three decades of corneal transplantation: indications and patient characteristics. Cornea. 2000;19(1):7-11.

18. Patel NP, Kim T, Rapuano CJ, Cohen EJ, Laibson PR. Indications for and outcomes of repeat penetrating keratoplasty, 1989-1995. Ophthalmology. 2000;107(4):719-24.

19. Siganos CS, Tsiklis NS, Miltsakakis DG, Georgiadis NS, Georgiadou IN, Kymionis GD, et al. Changing indications for penetrating keratoplasty in Greece, 1982-2006: a multicenter study. Cornea. 2010;29(4):372-4.

20. Yahalom C, Mechoulam H, Solomon A, Raiskup FD, Peer J, FruchtPery J. Forty years of changing indications in penetrating keratoplasty in Israel. Cornea. 2005;24(3):256-8.

21. Edwards M, Clover GM, Brookes N, Pendergrast D, Chaulk J, McGhee CN. Indications for corneal transplantation in New Zealand: 1991-1999. Cornea. 2002;21(2):152-5.

22. Kanavi MR, Javadi MA, Sanagoo M. Indications for penetrating keratoplasty in Iran. Cornea. 2007;26(5):561-3.

23. Legeais JM, Parc C, d'Hermies F, Pouliquen Y, Renard G. Nineteen years of penetrating keratoplasty in the Hotel-Dieu Hospital in Paris. Cornea. 2001;20(6):603-6.

24. Kang PC, Klintworth GK, Kim T, Carlson AN, Adelman R, Stinnett $\mathrm{S}$, et al. Trends in the indications for penetrating keratoplasty, 1980-2001. Cornea. 2005;24(7):801-3.

25. Instituto Brasileiro de Geografia e Estatística - IBGE. Divisão regional. [Internet]. [citado 2012 Mar 23]. Disponível em: http:/ /www.ibge.gov.br/home/geociencias/geografia/ default_div_int.shtm?c=1.

26. Silva CA, Oliveira ES, Sena Júnior MP, Souza LB. Comparação da sensibilidade ao contraste entre transplante lamelar anterior profundo e transplante penetrante para tratamento do ceratocone. Arq Bras Oftalmol. 2008;71(1):71-4.

27. Pimentel LN, Caldas DL, Valbon BF, Canedo AL, Ramos IC. Ceratoplastia em crianças: indicações e resultados. Rev Bras Oftalmol. 2011;70(2):99-103.

\section{Corresponding author:}

Caio Augusto Schlindwein Botelho

Rua Nicola Fassina, 253 - Jardim Botânico

CEP 13106-202 - Campinas/SP - Brazil

E-mail: caio_schlind@hotmail.com 